\title{
Difficulty Analysis Learning Mathematics Society and Factors Cause for Junior Secondary Students
}

\author{
Rizki Sariningtias*, Noviana Kusumawardani, Ali yasfi, Agil Syafaat, Ro'ikhatul Aliyah \\ Mathematics Education, Faculty of Teacher Training and Education, Tidar University \\ Jl. Kapten Suparman No 39 Magelang, Indonesia. Tel. (0293) 364113, Fax. (0293)362438, \\ Email*: riskisariningtias@gmail.com
}

\begin{abstract}
The study aims to describe the type of learning difficulties and factors of the learning difficulties of students of class VII SMP N 4 Satu Atap Pakis in studying mathematics subjects on the set material. The type and approach in this research is a type of descriptive research with a qualitative approach. The data collection techniques in this study are with diagnostic tests, polls, and interviews. From the results of the study came the conclusion that the difficulties of students of class VII SMP N 4 Satu Atap Pakis in the material set is a) difficulty understanding the question b) difficulty understanding the mathematical symbols and can not find the keywords of the problem, c) difficulties Transforming the problem, d) difficulties in completing the problem. While the learning difficulty factor is caused by two factors that are internal and external factors. internal factors include: a) lack of interest in students, b) lack of motivation to learn, c) lack of confidence to ask. External factors, among others: a) The class atmosphere is not conducive, b) the influence of handphone in the student concentration, c) lack of parental assistance in supervision at home.
\end{abstract}

Keywords: Difficulty Learning, Learning Difficulty Factors, Mathematics, Association

\section{INTRODUCTION}

Studying good mathematics according to Rusfendi (in Fakhrul Jamal: 2014), which is for the students to understand and understand the concept of mathematics, should be taught in the subsequent order of pure concept with applied concepts, in addition to being adapted to the Learning levels of the students.

In conducting students ' learning activities does not always work, there are often things that cause failure. The causes of failures include threats from the surrounding environment, the difficulties of learning the students, and the barriers from inside or outside students. This learning difficulty occurs because students experience obstacles and distractions. For example, it cannot associate a new lesson with a long lesson. Similarly, the mathematical subjects, the symptoms of learning difficulties will be seen when students are unable to master the material, so that the students obtain less fulfilling learning outcomes.

According to Syaiful Bahri Djamarah (2003:201) difficulty in learning is a condition where the students can not learn reasonably, because of threats, obstacles or disturbance in learning. The difficulties experienced by students resulted in the learning process being obstructed, not infrequently students have to repeat only because of difficulty studying academically.

Difficulty learning is a translation of the term learning English means learning and disability means inability, so that the correct translation should be a learning disability (Abdurrahman, 2003). These learning difficulties can be addressed if we as teachers or parents know the cause or Faktor-faktornya. Then once known the cause, teachers and parents can give or find a solution of the learning difficulties.

Ahmadi (2008) said that the factors of the students ' learning difficulties are internal factors and external factors. Internal factors consist of psychological factors that include intelligence, interest, talent, mental health, specific types of learning, as well as physiological factors including health factors, body defects. External factors consist of a family environment that includes the way parents educate children, the relationships between family members, the home atmosphere, and the family economic situation, the Community environment includes activities or activities of students in the community, friends Media, and neighboring environments, as well as school environments that include teaching teachers, teacher and student relationships, lesson supporting tools, building conditions, school time, school discipline, and school curriculum.

\section{MATERIALS AND METHODS}

The type used in this study is a qualitative descriptive research. Qualitative research was chosen to know deeper and detailed issues to be examined. The subject in this study was a grade VII student of SMP N 4 One roofing fern which was taken randomly by 10 students from 42 students. The collection of data in this study uses interviews and documentation through the filling of polls and the introduction of questions. The 
determination of the subject in this research is based on the results of the filling and execution of questions done by students of class VII., where the results of the filling and the work of the question is made a reference to know the difficulties of students and external and internal factors cause learning difficulties. The data analysis techniques used in this study are the data analysis models of Miles and Huberman that include data returns, data reduction, data presentation, and withdrawal of conclusions.

\section{RESULT AND DISCUSSION}

Based on the results of the filling of the poll which is 10 students and work about the students are obtained data about the difficulties experienced by students in learning mathematics and factors of the cause. Here's the description of the difficulties and factors of the cause.Kesulitan-Kesulitan yang dialami siswa

\section{Trouble Understanding the problem}

Difficulty in understanding the problem is difficulties in the form of students are able to read all the words in question but do not understand or understand the overall meaning of the words in question, so that students can not go further along the problem solving appropriate. Therefore, students cannot write down what is known and what is asked of the question. In the matter of stating the set and registering members of the set, students have difficulty writing what is known and what is asked questions. The location of difficulties experienced by students in understanding the problem can be seen in the students ' answers to the questions given.

1. a. $\{$ voli, pingpong, basket, sepakbola $\}$
b. $\{44,48,52,56,62, \ldots\}$

In question No. 1 of students ' work appears that students have difficulty understanding the problem, i.e. students cannot understand what was asked in the question. It should be that students can understand what is known and what is asked. Then new students can step into the next step and complete the question. From the results of the work, students demonstrate that the location of students ' difficulties is when students understand the words that are in the mathematical symbols that are in question. There are three students who have difficulty understanding the problem.

The difficulty of understanding this problem is due to the mindset of students who consider the mathematical symbols complicated, so that students struggle to interpret the mathematical symbols and not be able to find the keywords of the question. It is in line with the research result of Murdanu (2004) which says that students ' difficulties include: difficulty interpreting the information in question, language difficulties, difficulty understanding concepts and principles in geometry and Technical difficulties. Students who are unable to write down what is learned and asked questions of the problem will have difficulty in determining the next step or subsequent procedure so that the problem given is not resolved properly. This is because translating the problem is the basic ability to understand the problem for the first step of solving the problem.

\section{Trouble transforming the problem}

Difficulty in transforming the problem is the difficulties of students in determining the formula that should be used to solve the problem. Location of the student's difficulties lies in question number 3. Students ' work can be seen in the following image:

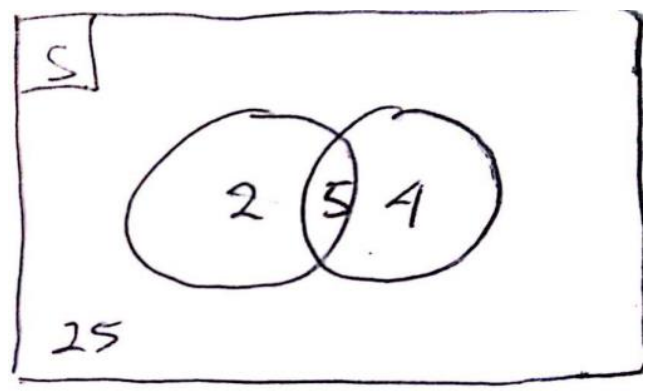

The student work above can be noted that students are able to understand what is known and what to ask. But students have not been able to transform, i.e. students forget the completion formula looking for many children who do not love both. Students should be able to finish with the formula not to love both $=\mathrm{S}-$ (Love the Math + Love Mathematics + both likes). After you get a child who loves science and who love Mathematics alone, only a child who does not love both. The location of difficulty at No. 3 is that students are not able to write the formula appropriately due to learning students who only memorize the formula so that students quickly forget with the formula and the material delivered. There are 3 students who are struggling to transform problems.

It is in line with research conducted by Retno Dewi Tanjungsari (2012) who concluded that:

1) difficulty in translating (linguistic knowledge) is aimed at mistakes in interpreting the language of the

2) difficulty in using principles, demonstrated students are not able to understand the variables, lack of algebraic mastery and lack of understanding ability (Scematic Knowlegde) shown with errors in altering the form of equations, mistakes in Algebraic computing, difficulties in implementing principles and errors of operating numbers

3) difficulty in using concepts aimed at the inability to remember the concept, the inability to dereduce the concept information and the lack of ability to 
understand (scematic knowledge) indicated with less complete in writing the formula

4) difficulties in the ability of algorithms include the lack of planning (strategy knowledge) and in the capability of completion (algorithmic) is demonstrated by not working on the problem, unfinished, lack of thoroughness to do.

In this case the researcher is in line with the result of Retno Dewi Tanjungsari, DKK on the third point. Students who are unable to recall concepts, degrade concept information and do not understand the concept are students who are unable to write a complete formula or cannot write down what procedures should be chosen. In addition, the difficulty in this model is if the student is able to degrade the concept and can write the formula or procedure well but can not use it properly to solve the problem.

\section{Difficulty in completing the problem}

The difficulty in solving the problem is the difficulty in performing a calculated and less thorough operation when the process finds an answer. The student work in question number 4 is as follows:

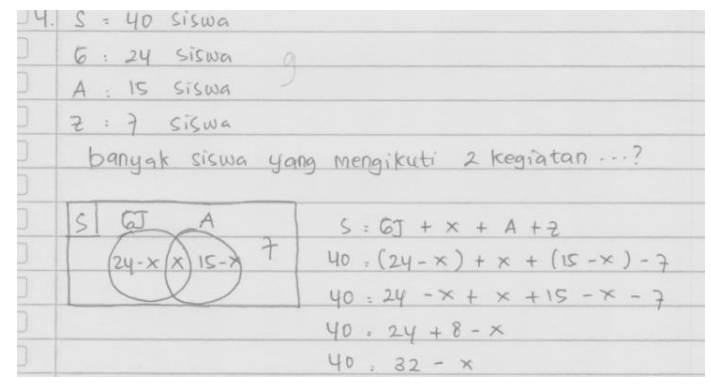

In the process of work is correct, but when students are faced with a counting operation that moved the segment of students still have difficulties. The initial step of the student in the work of changing the diagram of the addition and reduction operations is correct, and the students are able to perform the addition operation and reduction of algebraic form on the same section. But when looking for the $\mathrm{X}$ value, students have difficulty because they are not able to perform the counting operations in two sections. There are 4 students with difficulties

In the procedure of working on Question No. 4 is correct, only when students are faced with the addition and reduction of numbers by moving between the students are still experiencing difficulties, this causes students to be unable to solve the question of Den The truth. The initial step of the student in changing the story to the Venn diagram and from the Venn diagram to the mathematical sentence form is correct but when it comes to the transfer of the counting operations between the students still having difficulties and unable to solve the problem. Students who are in the category of difficulties in solving the problem are the students who make mistakes in the calculation process in solving steps. In this case, the students are not careful or thorough in doing such calculations in reducing and not able to operate the addition and reduction of the two segments.

\section{External and internal factors cause learning difficulties of students}

In the results of the poll conducted class VII students look at several external and internal factors that affect students ' math learning difficulties. These external factors are the environmental factors of the school, the family environment and environmental factors.

Judging by the outcome of the poll shows that students have difficulty learning that is influenced by the classroom environment. Classroom atmosphere is less conducive to making the learning process disturbed. This resulted in students experiencing difficulties in learning. In addition, teachers are also factors that cause students to have difficulty learning. Teachers must be able to master the class and have good material delivery skills. Lack of parental assistance when studying at home also affects the learning difficulties of the students. Parental assistance when students study at home is very important because it will inspire a passion for learning and students can ask a study companion when they encounter questions that are considered difficult. Conversely, if when students are not accompanied at home study will cause a sense of laziness and despair if the students encounter questions that are considered difficult.

While the school's environmental factors are time to study school and classroom environment. Student learning time affects students ' readiness to receive lesson materials. If the learning time is done in the morning then the student's interest is still high, because the energy and spirit of learning is still fresh. Instead they will feel saturated and tired if the learning time is done during the day. In addition, the influence of the crowded classroom situation during the day increasingly makes students unprepared to receive lessons well.

The less conducive classroom environment makes students less concentrated during the hours of the lesson. From the atmosphere of the lack of supportive class, difficulties arise students learn mathematics. It can be concluded that the school environment factors which include learning resources for mathematics in schools, mathematics learning facilities at school, mathematics learning situation at school and the condition of learning mathematics at school.

It is also strengthened by the research conducted by Suhas Caryono and Suhartono (2012) which concluded that (a) the average number of students who feel disturbed due to various physiology factor constraints as much as 10 students or $8 \%$ of all samples, (b) The average number of psychological factors amounting to 44 students or $35 \%$ showed that the factor is the largest choice of the five factors that cause learning difficulties, (c) The average number of school environmental factors that cause difficulties Learning mathematics is chosen by students as many as 25 
students or $20 \%$ of research samples, (d) The average number of family environmental factors as many as 21 students or $15 \%$ samples, and (e) The average number of community environments by 28 students or $21 \%$ samples.

Many class VII students simply memorize the formula and that results in students quickly forgetting the formula and the subject matter, causing students to be unable to properly resolve the set's questions.

Internal factors influencing the difficulty of learning students in grade VII SMP N 4 One roof Pakis as follows:

- Lack of motivation to students while following learning so that when students study lazing

- Lack or his friend

- Lack of of confidence in students, so that when experiencing difficulties students do not dare ask the teacher student interest in the set material

\section{Discussion}

The research has been known to learn difficulties and what factors cause it. These learning difficulties can be addressed if we as teachers or parents know the cause or Faktor-faktornya. Then once known the cause, teachers and parents can give or find a solution of the learning difficulties.

\section{CONCLUSION}

Based on the results of data analysis and the discussion that has been outlined in the previous chapter, it can be concluded: 1) The types of mathematical learning difficulties students experience in the chapter set can be classified into 3 types, namely difficulty understanding the problem, Difficulty in transforming problems, difficulty solving problems. 2) internal factors that have difficulty learning mathematics include: lack of student interest in the set material, lack of motivation to students when following learning so that when students ' learning lazing, lack of confidence Students, so that when experiencing difficulties students dare not ask their teachers or friends. 3) external factors that cause math learning difficulties are among them: the class atmosphere is less conducive, the influence of handphone that interfere with the centration of learning students, lack of parental assistance when students study at home

\section{ACKNOWLEDGEMENTS}

We thank for all who assisted in the preparation of the article titled The Analysis Of Difficulty Of Learning Mathematics Material Sets And The Causative Factors Is In Junior High School Students, thank to reviewers who have contributed their skills and their availability in reviewing the manuscript. To evaluate and assess articles submitted for consideration in the publication process. This is very important for the next process in this article.

\section{REFERENCES}

Abdurrahman, M. 2003. Pendidikan bagi Anak Berkesulitan Belajar. Jakarta: PT. Rineka Cipta

Caryono, Suhas \& Suhartono. 2012. Analisis Deskriptif Faktor Penyebab Kesulitan Belajar Mata Pelajaran Matematika Di SMA Negeri 8 Purworejo Tahun Peljaran 2012/2013. Prosiding Seminar Nasional Matematika dan Pendidikan Matematika FMIPA UNY.

Dewi, Retno Tanjungsari, dkk. 2012. Diagnosis Kesulitan Belajar Matematika SMP Pada Materi Persamaan Garis Lurus. Unnes Journal of Mathematics.

Djamarah, Syaiful Bahri. 2003. Psikologi Belajar. Jakarta: Rineka Cipta.

Dwidarti, Ulfi. Danang Setyadi. (2019). Analisis Kesulitan Siswa dalam Menyelesaikan Soal Cerita Pada Materi Himpunan. Jurnal Cendekia. Vol 3 No 2. jcup.org/index.php/cendekia.ac.id.

Febriansyah, Reza. Edy Yusmin, Asep Nursangaji. (2014). Analisis Kesulitan Siswa Dalam Memahami Materi Persamaan Liniar Dua Variabel di Kelas X SMA. Jurnal Pendidikan Dan Pembelajaran Katulistiwa. Vol 3 No 2. jurnal.untan.ac.id.

Indra, Nely Meifiani. 2011. Prosiding. Analisis Kesulitan Matematika Siswa SMP di Pacitan pada Ujian Nasional Tahun 2009/2010.

Jamal, Fakhrul. 2014. Analisis Kesulitan Belajar Siswa Dalam Mata Pelajaran Matemtaika Pada Materi Peluang Kelas XI IPA SMA Muhammadiyah Meulaboh Johan Pahlawan. Jurnal MAJU (Jurnal Pendidikan Matematika) Vol.1 No.1:18-36

Loru Milla, Meriana. Firda Alfiana. Raras Kartika. (2018). Analisis Kesulitan Berfikir Fisual Dalam Memahami Konsep pada Materi Himpunan. Jurnal Prasmatika. Vol 1 No 1. Https://doi.org/10.33503/prismatika.v1i1.305.

Maftukhah, Lina. 2012. Faktor-Faktor Yang Mempengaruhi Kesulitan Belajar IPS Terpadu Kelas VII di Smp Negeri 1 Platungan Kaupaten Kendal. Jurnal EEAJ (Economic Education Analysis Journal)

Nugraha, Nurlaela. Gida Kadarisma. Wahyu Setiawan. (2019). Analisis Kesulitan Belajar Matematika Materi Bentuk Aljabar Pada Siswa SMP Kelas VII. Journal on Education. 01, 323334.

Pradika, kurnia, dkk. 2014. Analisis Faktor Eksternal Penyebab Kesulitan Belajar Mata Pelajaran Matematika Siswa Kelas VIII MTS Amal Sholeh Kecamatan Getasan. Salatiga.

Pratiwi, Wimar Nabila Fauziah and, Rita P. Khotimah, S, Si., M. Sc. (2016) Analisis Kesulitan Belajar Siswa Pada Materi Himpunan Di Smp Muhammadiyah 10 Surakarta Tahun Pelajaran 2015/2016. Skripsi thesis, Universitas Muhammadiyah Surakarta.

Rachmadi, W. 2008. Diagnosis Kesulitan Belajar Matematika SMP dan Alternatif Proses Remidinya. Yogyakarta: Pusat Pengembangan dan Pemberdayaan Pendidikan dan Tenaga Kependidikan Matematika.

Slameto. 2003. Belajar dan Faktor - Faktor Yang Mempengaruhi. Jakarta: Rineka Cipta 